定的に反映されるようになった。そこで、「診断情報をキーワード に，画像処理パラメータの再搆築」を検討したので報告する。 【方法】1】各部位における撮影方向ごとの診断情報の整理. 2)低コ ントラスト微細搆造物の描出についてのハウレットチャートによる 視覚評価. 3)骨封入ファントムによる視覚評価.

【結果・考察】FIX modeによって再構築された画像処理パラメータ は、1)画像の提供者として意図した診断情報の高い画像を提供す ることができた．2)AUTO modeでの習慣からの脱却が大きな課 題となったが，画像の提供者として責任の自覚と意識の向上をもた らした.

\section{X缐模䈯 11}

座長 筑波大学医学部附属病院 横田 浩

\section{40歳代のマンモグラフィにおける乳癌描出能の検討}

群馬県立がんセンター 町田利彦、他 6 名

【目的】乳がん検診において，現行の視触診に加えてマンモグラフィ あるいは超音波による併用検診が検討されている.乳がんの䍜患率 の最も高い40歳代はデンスブレストが多くマンモグラフィ併用検 診には不向きの意見もあるが，40歳代の乳がん手術症例からマン モグラフィと超音波による乳がん描出能を検討する.

【方法】会員の所属する県内 4 施設の1996年度の40歳代の乳がん患 者53名(うち両側乳がん 2 名、全55症例)のマンモグラフィを、病 変の描出能について検討を加えた。また同時期の超音波検查施行例 については，両者の比較も検討した。

【結果】55症例のうち、デンスブレストと思われる症例は31、この うち $2 \mathrm{~cm}$ 以下の乳がんは14例中13例がマンモグラフィで描出され ていた．精度管理を適正に行い，品質の高いマンモグラフィを提供 することにより40歳代のマンモグラフィ併用検診にも対応でき る.

\section{CR共同利用システムにおけるMMGの評価}

藤沢市保健医療センター 鹿又伸男。他 1 名

【目的〕CR共同利用システム(以下，CR共同利用)に加入している各 施設のMMGを従来のF/S法とCR共同利用で, 各々の評価を行い, CR共同利用の有用性を検討した。

【方法】ACR認可・RMI型156型ファントームを各施設で従来のFI S法とCR共同利用で，撮影・処理し，ACR認可プログラムの得点 評洒方式を用いて、評価表を作成した。

【結果】評価表から、CR共同利用を用いることにより，採点の向上 が見られ，特にmass評価については，CRの特徴が良く表れた結 果となった。以上のことから，CR共同利用は，地域のMMGの精 度向上に有用なシステムと考えられた。

36 CRにおけるロスフィルムおよび撮影ミス集計分析の有用性 神奈川県立こども医療センター 小烟欣也，他 2 名

【目的】ロスフィルムおよび最影ミス(以下，ロス・ミス)の集計を行 いそその原因を分析することにより，改善策や軽隇策を考察し，口 ス・ミスを減らすことを目的とする.

ら方法所定のロス・ミス集計用紙に逐次記入し，会議においてその ロス・ミス分類を決定し、結果をコンピュータに入カし，集計す る. 集計は撮影系、処理系の 2 系列に区分し、それぞれ詳細な項 目別に分類し、種々の分析を行う。

【結果】集計結果を分析することにより，ロス・ミスの原因や処理ミ ス頻度の高い登録メニューが明らかとなり，対策を講じることがで き，有用であった。

【考察】撮影系に関しては，われわれの絶え間ない努力でロス・ミス を減らすことが可能である。しかし，処理ミスに関しては、メニュ 一のヒストグラム解析や最適メニューの開発等メーカに頼らざるを 得ない状況にあり，集計結果を基にアプローチしていきたい。

\section{管理(缐量管理)}

座長 甲府共立病院 野口保男

\section{7 心歲カテーテル椿㚗における患者皮膚被曝線量}

埼玉県立小原循環器病センター 久保田正男。他 3 名 【目的】患者皮膚線量を実測し，当院心カテにおける被曝の現状を明 らかにする。

【方法11)skin dose monitor，胸部ファントムを用い，当院摽準の アンギュレーションにて検出器を照射野の中心に各々固定し 1 検 查当たり（透視13分．撮影多方向。撮影時間 8 秒)の患者皮膚線量
を測定した．2)主治医および患者同意の上でRAO30にてLV中腔に 位置するよう患者皮膚面に検出器を固定し，実際の皮膚線量を測定 した（CAG 5 件，PTCA 2 件，透視検査 1 件，ABL 1 件).

【結果】ファントム実験では，1検査当たり)803.mGy (CAG 15 frame/sec, LVG 30frame/sec), 1359.8mGy (CAG 30frame/ sec, LVG 30frame/sec)であった.

【考察】1)skin dose monitorはリアルタイムで入射面積皮唐線量が 測定でき，放射線被曝の実態を知る上で有用である．2）心力テの ような多方向透視・撮影をする検査では必ずしもその実態を表して いないものの，患者皮䖉線量を知る上での一介となりうる。 3)EPS.ABL時の患者皮膚線量はほぼ正確に把握できると思われる。

\section{8 リアルタイム積算線量計(スキンドーズモニタ)を用いた被 異線量の測定}

厚生連熊谷総合病院 尾川光弘，他 7 名

患者の被曝防護を図るためには，まず被曝線量を知る必要があ る、線量計やTLDを用いて被曝線量を測定するためには，高価な線 量計や，煩雑な手間を必要とし，個々の医療施設ごとに手軽に測定 はできない，今回，半導体検出器 (亜鉛カドミニウム)を用いたリア ルタイム積算皮唐線量計(スキンドーズモニタ)を使用する機会があ り，一般撮影における入射表面線量を測定したので報告する。 た, 表面線量簡易換算式を用いたNDD法との比較検討結果も併せ て報告する。

\section{9 スキンドーズモニタを用いた胸・腹部撮影における被曝線 量の測定}

埼玉県立小原循環器病センター 諸澄邦彦。他 7名

放射線管理研究会では，関東広域の268施設の胸・腹部撮影にお ける入射表面線量をTLDを用いて測定し、第41回関東・東京部会 合同研究発表会(川口)において報告した。埼玉県においても39施 設について，胸・腹部撮影の入射表面線量を測定し，胸部立位撮影 で0.16mGy，腹部卧位撮影で1.74mGyの平均線量を得た。今回， 積算型の皮膚線量計スキンドーズモニタ(SDM-104)を使用し、前 回の測定施設の胸・腹部撮影における入射表面線量を測定したの で、TLDによる測定結果と比較し報告する。 また、表面線量簡易換 算式を用いたNDD法との比較検討結果も併せて報告する.

\section{0 シネ収集レート12.5F/sにおける放射線診療従事者の被曝 の現状 \\ 横浜労災病院 大澤充宏. 他 7名}

【目的l近年，IVRの増加に伴い，検者をはじめ放射線診療従事者の 被曝が問題となっている。.今回，年間約 1,450 例(診断カテ 850 例，IVR 500例，その他 100例)の当院現状を踏まえ，放射線診療 従事者の被曝低減を目的に運用している収集レート12.5F/sでの心 カテ室内散乱線および積算線量を測定したので報告する。

【方法】1)当院 2 心力テ室内(フィリップス社製・シングル\&バイプ レーン仕様〉の 8 カ所にフィルムバッジを設置し， 1 週〜 1 カ月間 の積算線量を測定し、測定期間中の検查件数から分析した，2）ラド カル社製mah線量計，ビクトリン社製ディジタル電離箱サーベイメ 一タ405型を使用し，各撮像方向，条件下で散乱線を測定した。 【結果・考察】1 cm線量当量では，検者の甲状腺、生殖腺の測定位置 で、各々 $3.5 \& 10 \mathrm{mSv} /$ 月の測定結果が得られた。被曝低隇には, フィルム現像処理系，装置システム系、防護系等々，これまでに様 々な検討が行われてきたが、診療上の要件を満たすものであれば， 収集レート12.5F/sは年間症例数の分析からも被曝低減に大きく寄 与しているものと思われる.

\section{1 血管撮影装置における最新の被曝低減法 シーメンス旭メディテック（株） 伊藤慶作}

\section{X線防護农の損偒の評価}

横浜市立大学医学部附属浦舟病院 平野祉江、他 6 名 【目的】日常頻繁に使われているX線防護衣（以下，防護衣という)の 損傷状況を把握するとともに、今後の管理の指標とする. 【方法】対象としたのは，上記 2 施設で現在使用されている防護衣 (エプロン型)で，目視とX線透視で，損傷の有無とその程度，なら びに部位を調べた。損傷有については，その使用年数・鉛当量・使 用検査での違いを分析した。

【結果】防護衣の損傷率は，使用年数が増すほど，また鉛当量が小さ いものほど高かった．損傷箇所は，使用される検查により偏りが見 られた。また、線透視下のみで確認された損傷も存在した。 